\title{
Distribution of $\alpha$ B-Crystallin in the Central Retina and Optic Nerve Head of Different Mammals and its Changes during Outer and Inner Retinal Degeneration Christian Albrecht May*
}

Department of Anatomy, Technische Universität Dresden, Fetscherstr 17, 01307 Dresden, Germany

\begin{abstract}
Purpose: To investigate species differences in the distribution and localization of alpha B-crystallin (ABC) in the normal retina and optic nerve head region, and to describe changes during outer and inner retina degeneration.

Material and methods: Animals studied included mice, rats, cats, pigs, cows, and monkeys. Sections of the optic nerve and central retina were labeled with antibodies against ABC and glial fibrillary acidic protein (GFAP).

Results: $A B C$ was located in astrocytes and Muller cells with different intensities. During outer retina degeneration (dystrophic rat and Abyssinian cat), only late stages showed an increase in $A B C$ in the retina and optic nerve head. Inner retina degeneration in the glaucoma mouse model showed no increase of $A B C$. In the monkey glaucoma model, only the innermost layer of the optic nerve head showed increased labeling for $A B C$.

Conclusions: The distribution of $A B C$ is species dependent and is (excluding the mouse) present in the nerve fiber layer of the retina and in the optic nerve head (localization of astrocytes). Chronic retinal degeneration does not necessarily lead to an over-expression of $A B C$. While in outer retinal degeneration induction was predominantly present in late stages, pressure-induced glaucoma led to a specific increase in ABC already in early stages indicating a local stress-response in this region.
\end{abstract}

Keywords: Alpha B-crystallin; Astrocytes; Optic nerve; Central retina

\section{Introduction}

The small heat shock proteins alpha B-crystallin (ABC) and Hsp27 are chaperone molecules that maintain the integrity of intracellular processes during various types of stress. While Hsp27 is rather specific for the human and has only modified related proteins in other mammals (e.g. Hsp25 in rodents and birds) [1,2], ABC is a highly conserved protein that exists in nearly any species examined [3-6]. In previous work we could show that $\mathrm{ABC}$ is present in the retrolaminar optic nerve of numerous species including human, monkey, cow, pig, rat, and mouse $[7,8]$. The amount of $\mathrm{ABC}$ showed species differences but was homogenous within different age groups of a single species.

Under pathological conditions the expression level of $A B C$ frequently increases. For this reason it is considered to be a useful marker in a variety of neurodegenerative diseases [9]. Concerning ocular pathologies, an increase in $\mathrm{ABC}$ was described in the retrolaminar optic nerve of glaucomatous monkey eyes [8]. In vitro studies confirmed the increase of $\mathrm{ABC}$ in human optic nerve head astrocytes exposed to elevated hydrostatic pressure [10]. In the retina, intense light exposure increased the amount of $A B C$ in rod outer segments and retinal pigment epithelium [11]. During retinal degeneration in the rd mouse the increased $A B C$ expression was associated with glial cell reaction [12]. Only recently, $A B C$ secretion was described from the retinal pigmented epithelium and a neuroprotective role suggested [13].

The present study was designed to answer three major questions. A. Are there species differences in the distribution and localization of $\mathrm{ABC}$ in the normal retina and optic nerve head region? $\mathrm{B}$. Is an increase of $\mathrm{ABC}$ a general phenomenon during retinal degeneration? $\mathrm{C}$. Is there a difference in $\mathrm{ABC}$ labeling between outer (photoreceptor type) and inner (ganglion cell type) retina degeneration?

\section{Material and Methods}

Tissue samples of the central retina and optic nerve head region were collected from mouse, rat, cat, pig, cow, and monkey eyes. Most of the tissues were left-over from various other protocols: the cat eye samples were from a collaboration with Kristina Narfström (Uppsala, Sweden) [14-16], the monkey eye samples from a collaboration with Paul Kaufman (Madison, USA) [17,18], the DBA2/NNia mouse eyes from a collaboration with Thomas Mittag (New York, USA) [19-21]. Rat and other mouse eyes were from own breeding (the animals sacrificed by neck dissection) [22-24], pig and cow eyes from the slaughterhouse in Erlangen (Germany). All animals were kept and treated in accordance with the ARVO Statement for the Use of Animals in Ophthalmic and Vision Research and the local animal care statutes.

Normal eyes of six pink-eyed rdy $+/$ - Royal College of Surgeons (RCS) rats (3 weeks to 22 months of age; RCS +/-), five European mixed breed cats (1-6 years of age), one Abyssinian cat (4 years of age), five pigs (6-12 months of age), four cows (1-2 years of age), and seven cynomolgus monkeys (6-20 years of age) were collected. To study eyes with outer retinal degeneration, seven RCS rdy -/- animals (3 weeks to

*Corresponding author: Christian Albrecht May, Department of Anatomy, Technische Universität Dresden, Fetscherstr 17, 01307 Dresden, Germany, Tel: +49-351-4586105; Fax: +49-351-4586303; E-mail: Albrecht.May@mailbox.tudresden.de

Received October 15, 2013; Accepted January 28, 2014; Published January 30 2014

Citation: May CA (2014) Distribution of aB-Crystallin in the Central Retina and Optic Nerve Head of Different Mammals and its Changes during Outer and Inner Retinal Degeneration. J Veterinar Sci Technol 5: 155. doi:10.4172/2157. 7579.1000155

Copyright: (c) 2014 May CA. This is an open-access article distributed under the terms of the Creative Commons Attribution License, which permits unrestricted use, distribution, and reproduction in any medium, provided the original author and source are credited. 
Citation: May CA (2014) Distribution of aB-Crystallin in the Central Retina and Optic Nerve Head of Different Mammals and its Changes during Outer and Inner Retinal Degeneration. J Veterinar Sci Technol 5: 155. doi:10.4172/2157-7579.1000155

12 months of age; RCS -/-) and eight Abyssinian cats with various stages of retinal degeneration (1-8 years of age) were available. To study eyes with inner retinal degeneration, nine DBA2/NNia mice ( 2 to 23 months of age) and seven cynomolgus and rhesus monkeys (12-32 years of age) with unilateral laser-induced ocular hypertensive eyes were available.

All tissue samples were fixed 2-10 minutes after sacrification in 4\% paraformaldehyde for 4-6 hours, then either washed in phosphate buffered saline (PBS; pH 7.2-7.4) or shipped in 1\% paraformaldehyde to Erlangen.

Sagittal $14 \mu \mathrm{m}$ thick cryo-sections through the central retina and the optic nerve head region were performed and mounted on glass slides. Incubation with a polyclonal rabbit anti alphaB-crystallin antibody (dilution 1:400; antibody kindly provided by Hans Bloemendal, Nijmegen, The Netherlands) or a polyclonal rabbit anti glial fibrillary acidic protein (GFAP; dilution 1:500; BioGenex Laboratories, San Ramon, CA, USA) was performed over night in a moist chamber at room temperature. After rinsing in PBS, a fluorescein-conjugated goat anti rabbit Cy3 antibody (dilution 1:1000; Dianova, Hamburg, Germany) was added for 1 hour. The slides were rinsed again in PBS, mounted with Kaiser's glycerin gelatine and viewed with a fluorescence microscope (Aristoplan; Leica) at 40X to 400X magnifications.

\section{Results}

\section{Species differences in normal eyes with no ocular pathology}

Immuno fluorescence labeling of $\mathrm{ABC}$ revealed clear species differences in the retina and optic nerve head:

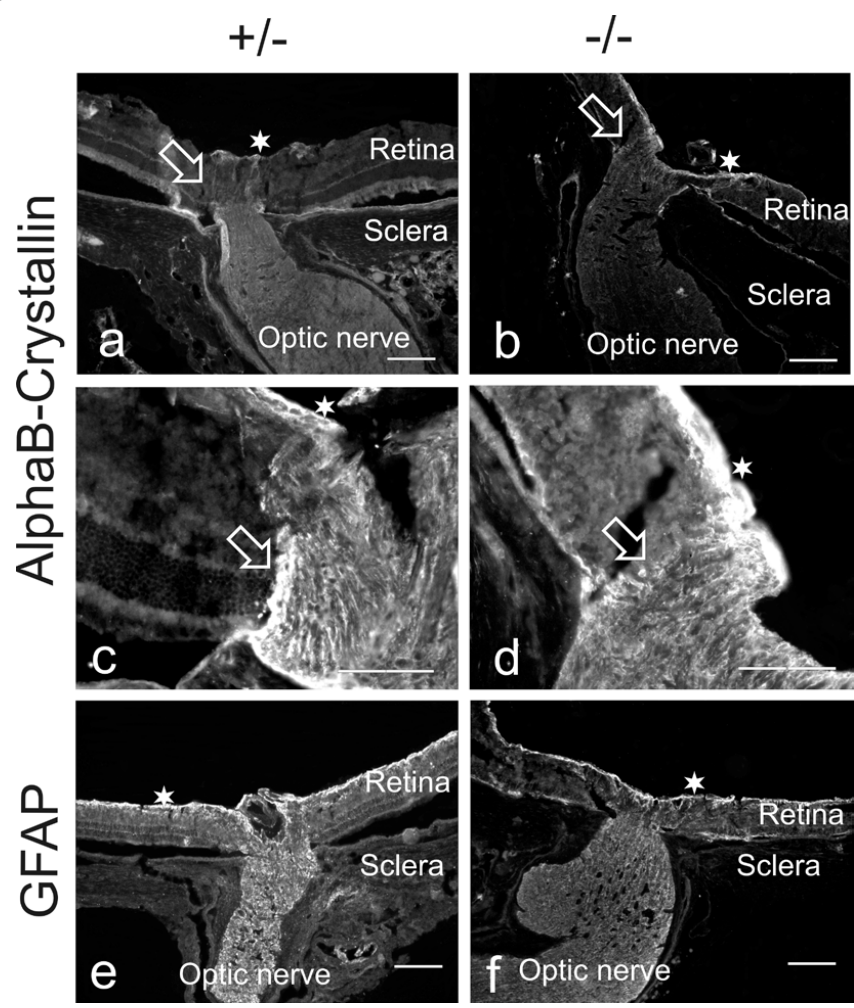

Figure 1: Micrographs through the optic nerve head of healthy $(+/-)$ and dystrophic (-/-) RCS rat eyes (both 12 months of age), stained for alphaBcrystallin and GFAP. The zone between the retina and the optic nerve head is marked with an open arrow. A star marks the inner retinal layer. A mild increase of alphaB-crystallin is only seen in the innermost layer of the optic nerve head (stars). Scale bar equals $100 \mu \mathrm{m}$

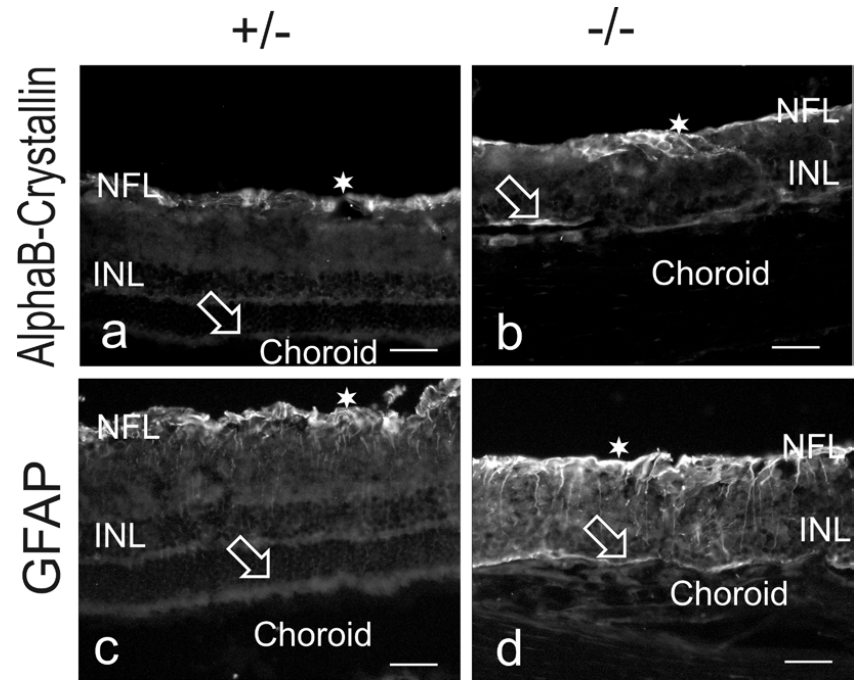

Figure 2: Micrographs through the central retina of healthy $(+/-)$ and dystrophic (-/-) RCS rat eyes (both 12 months of age), stained for alphaBcrystallin and GFAP. During outer retina dystrophy, some staining of alphaBcrystallin appeared at the outer limiting membrane (open arrow), presumably by single migrating astrocytes from the inner layers (star in $b$ ). Muller cells showed staining for GFAP but not for alphaB-crystallin. NFL=nerve fiber layer, $\mathrm{INL}=$ inner nuclear layer. Scale bar equals $50 \mu \mathrm{m}$.

In the rat optic nerve, cell processes in the lamina cribrosa and prelaminar region labeled for ABC (Figure 1a and 1c). The estimated density of these processes was less than that of processes labeled for GFAP (Figure 1e and 1f). In the innermost layer of the papilla region towards the inner limiting membrane, consistent labeling for $\mathrm{ABC}$ and GFAP was seen. Only single processes, presumably of astrocytes, in the nerve fiber layer (NFL) of the retina labeled for ABC; the Muller cells were not stained (Figure 2a). The distribution of GFAP was more intense in the NFL compared to $\mathrm{ABC}$ and indicated astrocytes and inner Muller cell processes (Figure 2c).

Consistent labeling for $\mathrm{ABC}$ was found in optic nerve head sections of the cat, pig and cow. Numerous positive staining was seen in the lamina cribrosa and prelaminar region of the optic nerve (Figure $3 \mathrm{a}$ and 3e), revealing a similar labeling pattern as GFAP (Figure 3c). Labeling of the innermost layer of the papilla region was more intense than the other optic nerve head regions. In the central retina, cell processes in the NFL (all animals) as well as single Muller cell processes (pig and cow) labeled positive for ABC (Figure $3 \mathrm{~b}$ and $3 \mathrm{f}$ ). GFAP showed intense labeling of the NFL of the central retina with no increase in the papilla region. Muller cells showed a much lower intensity in GFAP labeling (Figure 3d and 3g). Data of the cat not shown.

In normal monkey optic nerve specimens, the labeling distribution of $\mathrm{ABC}$ was comparable to that found in the cat, pig and cow (Figure $4 \mathrm{a}$ and $4 \mathrm{c})$.

\section{Eyes with inherited outer retinal degeneration}

In the dystrophic RCS -/- rat, labeling for ABC in the retro laminar optic nerve was similar to that observed in the normal animals. No changes occurred during retinal degeneration. At the innermost layer of the papilla region, an increase in labeling intensity was seen in the 12 months old dystrophic animals (Figure $1 \mathrm{~b}$ and $1 \mathrm{~d}$ ). Within the central retina, clear ABC labeling was seen only in the NFL (Figure 2b). The Muller cells, characterized by their long processes through the whole retina, became positive for GFAP only (Figure $2 \mathrm{~d}$ ). 
Citation: May CA (2014) Distribution of aB-Crystallin in the Central Retina and Optic Nerve Head of Different Mammals and its Changes during Outer and Inner Retinal Degeneration. J Veterinar Sci Technol 5: 155. doi:10.4172/2157-7579.1000155
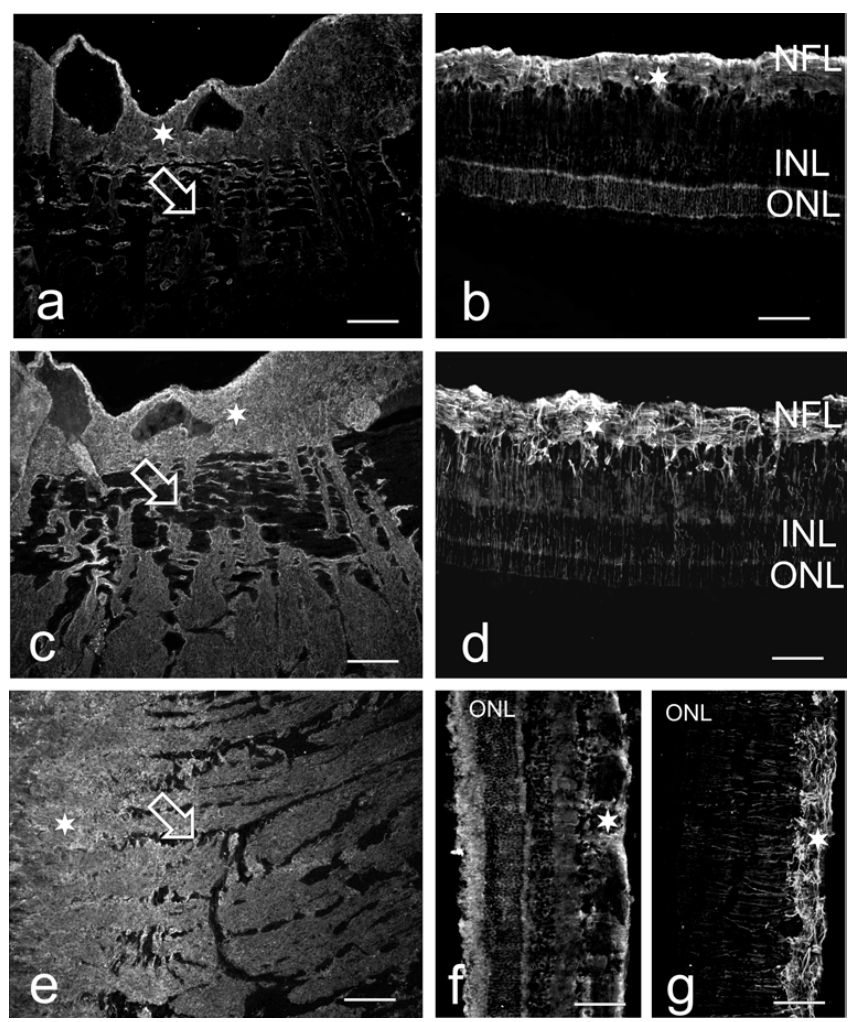

Figure 3: Micrographs through the optic nerve head (a,c,e; scale bar $200 \mu \mathrm{m})$ and central retina (b,d,f,g; scale bar $100 \mu \mathrm{m})$ of the porcine (a-d) and bovine $(e-g)$ eye, stained for alphaB-crystallin $(a, b, e, f)$ and GFAP $(c, d, g)$. Astrocytes in the lamina cribrosa (open arrow) and in the prelaminar region (stars in $a, c, e$ ) as well as in the nerve fiber layer of the retina (stars in b,d,f,g) staine positive for alphaB-crystallin. Single Muller cells show also alphaB-crystallin immunoreactivity, but less regular than GFAP (parallel stained lines through the retina in $\mathrm{d}, \mathrm{g}$ ). $\mathrm{NFL}=$ nerve fiber layer, INL=inner nuclear layer, $\mathrm{ONL}=$ outer nuclear layer.

In the Abyssinian cat, early stages (stage 0 and1) of retinal degeneration showed no changes in labeling for ABC and GFAP (data not shown). At later stages (stages 2-4), however, increase in $A B C$ labeling intensity at the papilla region and of the Muller cells occurred (Figure 5). GFAP positive Muller cells, in contrast, were seen only in the very late stages of retinal degeneration (stage 4 ; data not shown).

\section{Eyes with inner retinal degeneration (glaucomatous eyes)}

In rhesus monkeys, increase in intraocular pressure lead to an increase in $\mathrm{ABC}$ and GFAP staining mainly in the innermost layer of the papilla region towards the inner limiting membrane (Figure $4 \mathrm{~b}$ and $4 \mathrm{~d}$ ). This increase was consistent in all glaucomatous papillae studied, while the labeling intensity of the neuronal prelaminar and lamina cribrosa region showed inter-individual differences that were not correlated to the duration or severity of glaucomatous damage. In the central retina, labeling for $\mathrm{ABC}$ was restricted to the astrocytes in the NFL. No increase was noted in different stages of glaucomatous damage.

In the DBA2NNia strain, the overall distribution of $\mathrm{ABC}$ was not changed even in old animals with late stages of glaucomatous damage. The labeling was restricted to the retroocular myelinated part of the optic nerve. No labeling appeared in the papilla region or in the retina even in 20 months old animals with severe loss of retinal ganglion cells and optic nerve fibers (data not shown). There was also no visuable increase of $\mathrm{ABC}$ in the retina.
A semi-quantitative analysis summarizing the above described distribution of $\mathrm{ABC}$ is outlined in Table 1.

\section{Discussion}

1. The results of the present study show clear differences in the distribution of $\mathrm{ABC}$ in the retina and optic nerve head region between the different mammalian species studied. 2. During photoreceptor degeneration, an increase in $\mathrm{ABC}$ was only seen in late stages when the inner layers of the retina were also affected. 3. Retinal ganglion cell degeneration led to a specific early staining of the inner prepapillary region in the monkey glaucoma model.

A general problem when comparing different species and diseases is the affinity of the antibodies used. Proteins can become modified
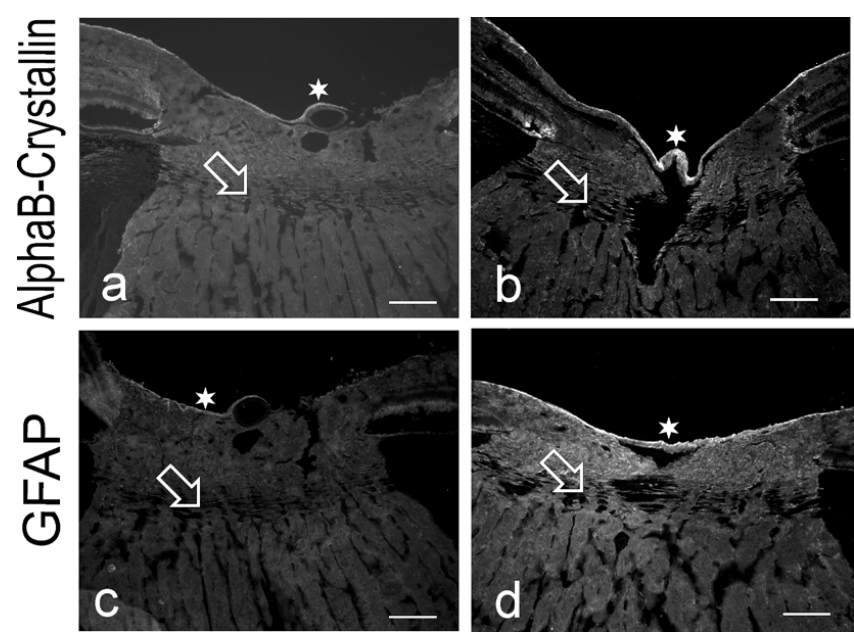

Figure 4: Micrographs through the optic nerve head of a healthy $(a, c)$ and glaucomatous (b,d) monkey eye (one animal, 12 years of age), stained for alphaB-crystallin and GFAP. The lamina cribrosa region (open arrow) and prelaminar region showed no staining difference between glaucoma and control for alphaB-crystallin, but a clear increase in GFAP. Only the innermost line of the optic nerve head (star) showed an increase in alphaB-crystallin staining. Scale bar equals $200 \mu \mathrm{m}$.
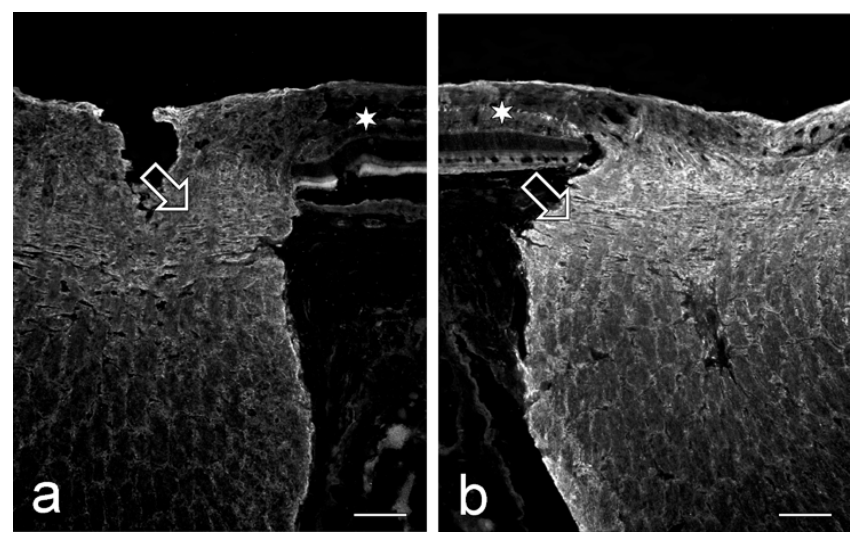

Figure 5: Micrographs through the optic nerve head of a healthy (a) and a dystrophic (stage 2, b) Abyssinian cat eye (both animals 4 years of age) stained for alphaB-crystallin. The homogenous staining in the normal eye (lamina cribrosa as indicated by the open arrow, prelaminar region, rim of the optic nerve bundles) is somewhat increased in the dystrophic eye. A star marks the retina which shows alphaB-crystallin staining in the nerve fiber layer. Scale bar equals $200 \mu \mathrm{m}$. 
Citation: May CA (2014) Distribution of aB-Crystallin in the Central Retina and Optic Nerve Head of Different Mammals and its Changes during Outer and Inner Retinal Degeneration. J Veterinar Sci Technol 5: 155. doi:10.4172/2157-7579.1000155

Page 4 of 6

\begin{tabular}{|c|c|c|c|c|c|c|c|}
\hline \multirow[t]{2}{*}{ Animals } & \multicolumn{3}{|c|}{ Retina } & \multicolumn{4}{|c|}{ Optic nerve head } \\
\hline & Nerve fiber layer & $\begin{array}{l}\text { Muller cell } \\
\text { processes }\end{array}$ & \begin{tabular}{|c|} 
Outer limiting \\
membrane region
\end{tabular} & $\begin{array}{l}\text { Inner layer towards inner } \\
\text { limiting membrane }\end{array}$ & $\begin{array}{l}\text { Pre-lamina } \\
\text { region }\end{array}$ & $\begin{array}{l}\text { Lamina cribrosa } \\
\text { region }\end{array}$ & $\begin{array}{l}\text { Post-lamina } \\
\text { region }\end{array}$ \\
\hline mouse (data from reference 39 ) & 0 & 0 & 0 & 0 & 0 & not existent & + \\
\hline Glaucoma mouse $(n=18)$ & 0 & 0 & 0 & 0 & 0 & not existent & + \\
\hline $\mathrm{RCS}+/-$ rat $(\mathrm{n}=12)$ & + & 0 & 0 & + & + & + & + \\
\hline RCS -/- rat $(n=14)$ & + & 0 & $\begin{array}{l}\text { e } 0 \\
\text { I (+) }\end{array}$ & ++ & + & + & + \\
\hline $\begin{array}{l}\text { European mix breed and } \\
\text { Abyssinian cat }(n=6)\end{array}$ & + & 0 & 0 & ++ & + & + & + \\
\hline RP Abyssinian cat $(n=8)$ & + & $\begin{array}{l}\text { e } 0 \\
\text { I (+) }\end{array}$ & 0 & ++ & $\begin{array}{c}e+ \\
\mathrm{I}++\end{array}$ & $\begin{array}{c}e+ \\
1++\end{array}$ & + \\
\hline pig $(n=5)$ & ++ & $(+)$ & 0 & ++ & + & + & + \\
\hline $\operatorname{cow}(n=4)$ & ++ & $(+)$ & 0 & ++ & + & + & + \\
\hline cynomolgus monkey $(n=12)$ & ++ & 0 & 0 & ++ & + & + & + \\
\hline $\begin{array}{l}\text { Glaucoma cynomolgus and } \\
\text { rhesus monkey } \\
(n=7)\end{array}$ & ++ & 0 & 0 & +++ & + & + & ++ \\
\hline
\end{tabular}

Table 1: Semiquantitative evaluation of alphaB-crystallin distribution in the retina and optic nerve head of various animals ( $n=$ number of eyes evaluated). $0=$ no staining; $(+)$ = single or inconsistent staining; $+=$ consistent mild staining; $++=$ consistent moderate staining; $+++=$ consistent strong staining. $e=$ early stages of disease, $I=$ late stages of disease.

with age, truncations can occur in degenerative conditions, and thus compromise the affinity. Unfortunately, there is no way to exclude these processes which could lead to misinterpretation. The following discussion is based on the described results and therefore reflects the actual staining performed with the specific antibody. Since the results do not contradict other statements and descriptions of $\mathrm{ABC}$, they might reflect the real situation.

Ad 1. Species differences were prominent between rodents and the other animals investigated in this study. Since chaperone molecules are highly related to various types of stress, a pure size-dependence of the eye (small versus large eyes) does not sufficiently interpret the findings. Two stress factors might more likely be causative: one is the absolute life span of the animals, the other one is the normal activity rhythm (nocturnal versus diurnal). A counter-example for the latter hypothesis is the fact that intense light exposure was shown to stimulate $A B C$ expression in rod outer segments but not in the inner retina [11].

For all animals it was interesting to note, that there was no $\mathrm{ABC}$ staining located within the neurons, but only within glial cells (constantly astrocytes, occasionally Muller cells). This is in contrast to other crystallins and small heat shock proteins which were also described in photo receptor cells and retinal ganglion cells [25-30]. On the other hand, the close relation of $\mathrm{ABC}$ to glial cells is not unique in the retina but also known in other neuronal tissues [9,31].

Ad 2. Even though retinal degeneration leads to an imbalance of the local homeostasis and therefore to stress-like conditions, increase of $\mathrm{ABC}$ is not an early phenomenon during outer retinal degeneration. In this type of retinal degeneration, the inner layers are well preserved for a long time. Only at late stages morphological alterations are paralleled by a different expression of $\mathrm{ABC}$. Heat shock protein protection seemed to appear earlier than fibrillar activation in glial cells, at least in the Abyssinian cat model. Increase of ABC was also reported in Muller cells and retinal astrocytes of the rd mouse with an accelerated type of degeneration [12].

Concerning other small heat shock proteins, a reduction of alphaAcrystallin seems to be present in the RCS rat already in early stages of the degeneration [32]. This lack of alphaA-crystallin might lead to a higher vulnerability of the photo receptors [33].
Ad 3. Increase of $A B C$ in glaucomatous optic nerves was reported $[8,10]$, but a precise localization has not been described so far. Interestingly, the mouse glaucoma model is not suitable for this type of investigations since $\mathrm{ABC}$ seems to play no major role in the mouse eye pathology. It is tempting to speculate that heat shock protein 27 might sufficiently serve the protective function in this species [34,35] and possibly in the rat, too [36].

The increase of $\mathrm{ABC}$ in the monkey glaucoma model showed a specific location at the inner papilla already in early stages of the disease. This unique location was not reported for other heat shock proteins [37] and might reflect a specific vulnerable region. It supports the hypothesized pathogenesis by Osborne [38] claiming the prelaminar region as the most sensitive part of the optic nerve fibers. An early and intense reaction of the local glial cells seems to take place, expressing not only ABC, but also GFAP and other factors like TGFbeta [39].

Numerous studies report an increase of $A B C$ within the first few days following an acute insult (diabetes, retinopathy of prematurity, ischemia; reviewed in Fort and Lampi [40]) or optic nerve damage $[41,42]$ but long term regulation is often neglected. In age-related macular degeneration $\mathrm{ABC}$ accumulation was described in drusen [4345 ] and recent interest is focused on this protein in the retinal pigmented epithelium [46,47]. Increase of ABC was reported in the glaucomatous retrolaminar optic nerve [8] and trabecular meshwork [48] and in a mouse model of outer retinal degeneration [12]. In this study, several models with chronic retinal destruction were studied concerning their distribution of $\mathrm{ABC}$. They show that during the process of outer retinal degeneration $\mathrm{ABC}$ expression is not greatly altered, suspecting no major protective mechanism of this molecule under these in vivo conditions. In contrast, the glaucoma monkey model showed an increase of $\mathrm{ABC}$ in the inner layer of the optic nerve head already in early stages of increased intraocular pressure which remained present in later stages. The early induction at this location points to an active role of $\mathrm{ABC}$ in vivo. Although effects of $\mathrm{ABC}$ are reported in and discussed for the retina [49], both types of retinal degeneration showed almost no changes of $\mathrm{ABC}$ labeling in the retina itself.

Since this study shows only mild and focused changes of $\mathrm{ABC}$ in a number of animal models with inner and outer retinal degeneration, future studies are required to more precisely describe the role of $\mathrm{ABC}$ in chronic, long-lasting situations. Chronic retinal diseases with vascular 
Citation: May CA (2014) Distribution of aB-Crystallin in the Central Retina and Optic Nerve Head of Different Mammals and its Changes during Outer and Inner Retinal Degeneration. J Veterinar Sci Technol 5: 155. doi:10.4172/2157-7579.1000155

involvement (e.g. diabetes) might help to further understand the role of $\mathrm{ABC}$, since new data points to a vascular regulating role of $\mathrm{ABC}$ [50] which might be more important than pure neuronal aspect. Induction of diabetes in rats showed an early increase of alpha-crystallins with a reduction at later time points [51], supporting the low levels described only recently in the human [52]. The vascular aspect, however, was not taken into account in these studies.

Acknowledgement: The print was supported by the Open Access Publication Funds of the TU Dresden.

\section{References}

1. Haslbeck M (2002) sHsps and their role in the chaperone network. Cell Mol Life Sci 59: 1649-1657.

2. Panasenko OO, Seit Nebi A, Bukach OV, Marston SB, Gusev NB (2002) Structure and properties of avian small heat shock protein with molecular weight $25 \mathrm{kDa}$. Biochim Biophys Acta 1601: 64-74.

3. Frederikse PH, Dubin RA, Haynes JI 2nd, Piatigorsky J (1994) Structure and alternate tissue-preferred transcription initiation of the mouse alpha B-crystallin/ small heat shock protein gene. Nucleic Acids Res 22: 5686-5694.

4. Liao JH, Hung CC, Lee JS, Wu SH, Chiou SH (1998) Characterization, cloning, and expression of porcine alpha $B$ crystallin. Biochem Biophys Res Commun 244: 131-137.

5. MacRae TH (2000) Structure and function of small heat shock/alpha-crystallin proteins: established concepts and emerging ideas. Cell Mol Life Sci 57: 899913

6. Horwitz J (2003) Alpha-crystallin. Exp Eye Res 76: 145-153.

7. Oertel MF, May CA, Bloemendal H, Lütjen-Drecoll E (2000) Alpha-B-crystallin expression in tissues derived from different species in different age groups. Ophthalmologica 214: 13-23.

8. Furuyoshi N, Furuyoshi M, May CA, Hayreh SS, Alm A, et al. (2000) Vascular and glial changes in the retrolaminar optic nerve in glaucomatous monkey eyes. Ophthalmologica 214: 24-32.

9. van Rijk AF, Bloemendal H (2000) Alpha-B-crystallin in neuropathology Ophthalmologica 214: 7-12

10. Salvador-Silva M, Ricard CS, Agapova OA, Yang P, Hernandez MR (2001) Expression of small heat shock proteins and intermediate filaments in the human optic nerve head astrocytes exposed to elevated hydrostatic pressure in vitro. J Neurosci Res 66: 59-73.

11. Sakaguchi H, Miyagi M, Darrow RM, Crabb JS, Hollyfield JG, et al. (2003) Intense light exposure changes the crystallin content in retina. Exp Eye Res 76: 131-133.

12. Jones SE, Jomary C, Grist J, Thomas MR, Neal MJ (1998) Expression of alphaB-crystallin in a mouse model of inherited retinal degeneration. Neuroreport 9: 4161-4165.

13. Sreekumar PG, Kannan R, Kitamura M, Spee C, Barron E, et al. (2010) Ît+B crystallin is apically secreted within exosomes by polarized human retinal pigment epithelium and provides neuroprotection to adjacent cells. PLoS One 5: e12578.

14. May CA, Lütjen-Drecoll E, Narfström K (2005) Morphological changes in the anterior segment of the Abyssinian cat eye with hereditary rod-cone degeneration. Curr Eye Res 30: 855-862.

15. May CA, Narfström K (2008) Choroidal microcirculation in Abyssinian cats with hereditary rod-cone degeneration. Exp Eye Res 86: 537-540.

16. May CA, Narfström K (2012) Retinal capillary morphology in the Abyssinian cat with hereditary retinal degeneration. Exp Eye Res 99: 45-47.

17. May CA, Hayreh SS, Furuyoshi N, Ossoinig K, Kaufman PL, et al. (1997) Choroidal ganglion cell plexus and retinal vasculature in monkeys with laserinduced glaucoma. Ophthalmologica 211: 161-171.

18. Albrecht May C, Kaufman PL, Lütjen-Drecoll E, Scholz M (2006) Choroidal innervation and optic neuropathy in macacque monkeys with laser- or anterior chamber perfusion-induced short-term elevation of intraocular pressure. Exp Eye Res 82: 1060-1067.
19. May CA, Mittag T (2004) Neuronal nitric oxide synthase (nNOS) positive retinal amacrine cells are altered in the DBA/2NNia mouse, a murine model for angleclosure glaucoma. J Glaucoma 13: 496-499.

20. May CA, Mittag T (2006) Optic nerve degeneration in the DBA/2NNia mouse: is the lamina cribrosa important in the development of glaucomatous optic neuropathy? Acta Neuropathol 111: 158-167.

21. May CA, Mittag T (2006) Vascular changes in the posterior eye segment of secondary angle-closure glaucoma: cause or consequence? Graefes Arch Clin Exp Ophthalmol 244: 1505-1511.

22. May CA, Horneber M, Lütjen-Drecoll E (1996) Quantitative and morphological changes of the choroid vasculature in RCS rats and their congenic controls. Exp Eye Res 63: 75-84.

23. Rexer M, May CA, Lütjen-Drecoll E (1998) Changes in choroidal innervation in Royal College of Surgeons rats with hereditary retinal degeneration. Acta Anat (Basel) 162: 112-118.

24. Neuhardt T, May CA, Wilsch C, Eichhorn M, Lütjen-Drecoll E (1999) Morphological changes of retinal pigment epithelium and choroid in rd-mice. Exp Eye Res 68: 75-83.

25. Deretic D, Aebersold RH, Morrison HD, Papermaster DS (1994) Alpha A- and alpha B-crystallin in the retina. Association with the post-Golgi compartment of frog retinal photoreceptors. J Biol Chem 269: 16853-16861.

26. Head MW, Sedowofia K, Clayton RM (1995) Beta B2-crystallin in the mammalian retina. Exp Eye Res 61: 423-428.

27. Segovia L, Horwitz J, Gasser R, Wistow G (1997) Two roles for mu-crystallin: a lens structural protein in diurnal marsupials and a possible enzyme in mammalian retinas. Mol Vis 3: 9 .

28. Jones SE, Jomary C, Grist J, Makwana J, Neal MJ (1999) Retinal expression of gamma-crystallins in the mouse. Invest Ophthalmol Vis Sci 40: 3017-3020.

29. Xi J, Farjo R, Yoshida S, Kern TS, Swaroop A, et al. (2003) A comprehensive analysis of the expression of crystallins in mouse retina. Mol Vis 9: 410-419.

30. Wistow G, Wyatt K, David L, Gao C, Bateman O, et al. (2005) gammaN-crystallin and the evolution of the betagamma-crystallin superfamily in vertebrates. FEBS J 272: 2276-2291.

31. Duvanel CB, Monnet-Tschudi F, Braissant O, Matthieu JM, Honegger $P$ (2004) Tumor necrosis factor-alpha and alphaB-crystallin up-regulation during antibody-mediated demyelination in vitro: a putative protective mechanism in oligodendrocytes. J Neurosci Res 78: 711-722.

32. Maeda A, Ohguro H, Maeda T, Nakagawa T, Kuroki Y (1999) Low expression of alphaA-crystallins and rhodopsin kinase of photoreceptors in retinal dystrophy rat. Invest Ophthalmol Vis Sci 40: 2788-2794.

33. Rao NA, Saraswathy S, Wu GS, Katselis GS, Wawrousek EF, et al. (2008) Elevated retina-specific expression of the small heat shock protein, alphaAcrystallin, is associated with photoreceptor protection in experimental uveitis. Invest Ophthalmol Vis Sci 49: 1161-1171.

34. Huang W, Fileta JB, Filippopoulos T, Ray A, Dobberfuhl A, et al. (2007) Hsp27 phosphorylation in experimental glaucoma. Invest Ophthalmol Vis Sci 48 4129-4135.

35. Yang Z, Quigley HA, Pease ME, Yang Y, Qian J, et al. (2007) Changes in gene expression in experimental glaucoma and optic nerve transection: the equilibrium between protective and detrimental mechanisms. Invest Ophthalmo Vis Sci 48: 5539-5548.

36. Kalesnykas G, Niittykoski M, Rantala J, Miettinen R, Salminen A, et al. (2007) The expression of heat shock protein 27 in retinal ganglion and glial cells in a rat glaucoma model. Neuroscience 150: 692-704.

37. Sakai M, Sakai H, Nakamura Y, Fukuchi T, Sawaguchi S (2003) Immunolocalization of heat shock proteins in the retina of normal monkey eyes and monkey eyes with laser-induced glaucoma. Jpn J Ophthalmol 47: 42-52.

38. Osborne NN (2008) Pathogenesis of ganglion "cell death" in glaucoma and neuroprotection: focus on ganglion cell axonal mitochondria. Prog Brain Res 173: $339-352$

39. May CA, Lütjen-Drecoll E (2002) Morphology of the murine optic nerve. Invest Ophthalmol Vis Sci 43: 2206-2212.

40. Fort PE, Lampi KJ (2011) New focus on alpha-crystallins in retina neurodegenerative diseases. Exp Eye Res 92: 98-103. 
Citation: May CA (2014) Distribution of aB-Crystallin in the Central Retina and Optic Nerve Head of Different Mammals and its Changes during Outer and Inner Retinal Degeneration. J Veterinar Sci Technol 5: 155. doi:10.4172/2157-7579.1000155

41. Ying $X$, Zhang J, Wang Y, Wu N, Wang Y, et al. (2008) Alpha-crystallin protected axons from optic nerve degeneration after crushing in rats. J Mol Neurosci 35: 253-258

42. Munemasa Y, Kwong JM, Caprioli J, Piri N (2009) The role of alphaA- and alphaB-crystallins in the survival of retinal ganglion cells after optic nerve axotomy. Invest Ophthalmol Vis Sci 50: 3869-3875.

43. Johnson PT, Brown MN, Pulliam BC, Anderson DH, Johnson LV (2005) Synaptic pathology, altered gene expression, and degeneration in photoreceptors impacted by drusen. Invest Ophthalmol Vis Sci 46: 4788-4795.

44. Umeda S, Suzuki MT, Okamoto H, Ono F, Mizota A, et al. (2005) Molecular composition of drusen and possible involvement of anti-retinal autoimmunity in two different forms of macular degeneration in cynomolgus monkey (Macaca fascicularis). FASEB J 19: 1683-1685.

45. Nakata K, Crabb JW, Hollyfield JG (2005) Crystallin distribution in Bruch's membrane-choroid complex from AMD and age-matched donor eyes. Exp Eye Res 80: 821-826.

46. Gangalum RK, Atanasov IC, Zhou ZH, Bhat SP (2011)AlphaB-crystallin is found in detergent-resistant membrane microdomains and is secreted via exosomes from human retinal pigment epithelial cells. J Biol Chem 286: 3261-3269.
47. Bhat SP, Gangalum RK (2011) Secretion of ÎtB-Crystallin via exosomes: New clues to the function of human retinal pigment epithelium. Commun Integr Biol 4: 739-741.

48. Lütjen-Drecoll E, May CA, Polansky JR, Johnson $\mathrm{DH}$, Bloemendal $\mathrm{H}$, et al. (1998) Localization of the stress proteins alpha B-crystallin and trabecular meshwork inducible glucocorticoid response protein in normal and glaucomatous trabecular meshwork. Invest Ophthalmol Vis Sci 39: 517-525.

49. McGreal RS, Kantorow WL, Chauss DC, Wei J, Brennan LA, et al. (2012) aB-crystallin/sHSP protects cytochrome $\mathrm{c}$ and mitochondrial function against oxidative stress in lens and retinal cells. Biochim Biophys Acta 1820: 921-930.

50. Kase S, He S, Sonoda S, Kitamura M, Spee C, et al. (2010) aB-crystallin regulation of angiogenesis by modulation of VEGF. Blood 115: 3398-3406.

51. Fort PE, Freeman WM, Losiewicz MK, Singh RS, Gardner TW (2009) The retina proteome in experimental diabetic retinopathy: up-regulation of crystallins and reversal by systemic and periocular insulin. Mol Cell Proteomics 8: 767-779.

52. Kase S, Ishida S, Rao NA (2011) Increased expression of aA-crystallin in human diabetic eye. Int J Mol Med 28: 505-511. 